\title{
Early diagnosis of subependymal giant cell astrocytoma in children with tuberous sclerosis
}

\author{
R Nabbout, M Santos, Y Rolland, O Delalande, O Dulac, C Chiron
}

\begin{abstract}
Objectives-Intraventricular astrocytomas (subependymal giant cell astrocytomas) of tuberous sclerosis have a poor prognosis due to the obstruction of CSF flow. The aim of this study was to determine whether they could be differentiated during childhood and at an early preclinical stage, from subependymal nodules without any growing potential.

Methods-The first two MRIs of all children referred to this neuropaediatric centre between 1987 and 1996 were retrospectively blindly reviewed.

Results-Out of 60 patients, 24 disclosed subependymal nodules localised near the foramen of Monro, and eight of the 24 developed astrocytomas. Subependymal nodules were first detectable on MRI from 1 year of age in all cases and the first MRI evidence of growth occurred between 1 and 9 years (mean 4 years). At an early stage, subependymal nodules had different characteristics in patients who developed subependymal giant cell astrocytomas from those who did not. The nodules over $5 \mathrm{~mm}$ in diameter that were incompletely calcified and enhanced by gadolinium were at higher risk of growing, particularly in children with a familial history of tuberous sclerosis.

To detect the subependymal giant cell astrocytomas earlier in tuberous sclerosis, it is advisible to systematically perform an MRI examination before 2 years of age and to repeat it every year if the patient has risk factors for developing astrocytomas.

(f Neurol Neurosurg Psychiatry 1999;66:370-375)
\end{abstract}

Radiology

Department, Hospital Saint-Vincent-de-Paul, and INSERM U29,

Paris, France

Y Rolland

Department of

Neurosurgery,

Fondation Rotschild,

Paris, France

O Delalande

Correspondence to:

Dr C Chiron, Service de

Neuropédiatrie, Hopital

Saint Vincent de Paul, 82

Avenue Denfert-Rocchereau,

75674 Paris, Cedex 14

France.

Received 26 September 1997 and in revised form 24 July

1998

Accepted 14 September 1998
Keywords: tuberous sclerosis; astrocytoma; children

Tuberous sclerosis is a neurocutaneous syndrome which produces various types of benign tumours involving various organs, such as rhabdomyomas in the heart, angiomyolipomas in the kidneys, and astrocytomas in the brain. The natural history of these tumours is different: rhabdomyomas tend to regress, astrocytomas may grow, whereas angiomyolipomas often degenerate. Whether and when a tumour due to tuberous sclerosis will grow seems to be unpredictable.

The most frequent neurological signs of tuberous sclerosis are epilepsy and mental retardation, which respectively affect about $80 \%$ and $60 \%$ of the patients whereas astrocytomas are present in $5 \%$ to $10 \%$ of the cases. ${ }^{1}$ Although these tumours are histologically benign and homogeneous in nature, consisting of subependymal giant cell astrocytomas, ${ }^{2-6}$ they have a potentially severe prognosis as they represent the major cause of death in tuberous sclerosis. ${ }^{7-11}$ When they grow, this results in the obstruction of CSF flow because they are localised near the foramen of Monro, on one or both sides. ${ }^{12} 13$

In children, 110 cases of subependymal giant cell astrocytomas have been reported in the literature. They were usually discovered after 10 years, at a mean age of 13 years. ${ }^{1415}$ All patients presented with clinical features of increased intracranial pressure ${ }^{8916-23}$ and when they underwent emergency surgery, the rate of mortality reached $10 \% .{ }^{12}$ In recent years, a more radical surgical approach has been recommended with an attempt to complete the resection of the tumour in a non-acute phase to improve the prognosis of these patients. ${ }^{12} 18$

The diagnosis of these tumours once they produce clinical signs and their relation to tuberous sclerosis is usually easy on CT or MRI. ${ }^{14}{ }^{24-26}$ However, it is difficult at an earlier stage to distinguish small masses consisting of subependymal nodules from subependymal giant cell astrocytomas as they both affect the area of the foramen of Monro. It is also difficult to predict tumour growth and therefore to establish a procedure for brain imaging follow up in a given patient with tuberous sclerosis.

The present study was performed with two objectives: (1) to verify whether tumours do exist in the paediatric population with tuberous sclerosis before the age of 10 years; (2) if so, to examine their radiological characteristics at an early preclinical stage to define potential risk factors for further growth.

\section{Patients and methods}

PATIENTS

We retrospectively reviewed the clinical and radiological records of children who presented with tuberous sclerosis and met the following criteria: (1) patients referred at the Saint Vincent de Paul Hospital between 1987 and 1996; (2) who had at least a 3 year follow up; (3) who had at least two MR scans during follow up, the first one during the year after diagnosis and the second during the last 2 years of follow up.

Sixty patients (32 girls and 28 boys) met these criteria.

Among them, we selected those who exhibited, on the last MRI, a mass located near the foramen of Monro. Patients with lesions elsewhere but no lesion near the foramen of Monro were excluded. There were 24 patients selected (40\%), 11 girls and 13 boys, 16 with 
Table 1 Patients without any detectable subependymal nodules (SEN) at first examination

\begin{tabular}{|c|c|c|c|c|c|c|c|c|}
\hline Patient & $\begin{array}{l}\text { Epilepsy } \\
\text { onset }\end{array}$ & $\begin{array}{l}\text { Type of } \\
\text { seizures }\end{array}$ & $\begin{array}{l}\text { Age at first } \\
\text { scan }\end{array}$ & $\begin{array}{l}\text { Age at 1rst } \\
\text { MRI }\end{array}$ & $\begin{array}{l}\text { Radiological } \\
\text { findings }\end{array}$ & $\begin{array}{l}\text { Age at the } \\
\text { detection of } \\
\text { SEN }\end{array}$ & $\begin{array}{l}\text { No of } \\
\text { examinations } \\
\text { between first } \\
\text { imaging and } \\
\text { detection of } \\
\text { SEN (age) }\end{array}$ & $\begin{array}{l}\text { Further } \\
\text { SEGA }\end{array}$ \\
\hline 1 & 1 month & PS & 2 months & 6 months & 1 frontal tuber & $5 \mathrm{y}$ & $1(11 \mathrm{~m})$ & + \\
\hline 2 & 1 month & PS & 2 months & $1 \mathrm{y}$ & no lesion & $12 \mathrm{y}$ & 0 & - \\
\hline 3 & 11 months & PS & 1 year & 18 months & 1 frontal tuber & $4 y$ & 1 ( 2 years) & - \\
\hline 4 & 3 months & IS & 8 months & 4 years & $\begin{array}{l}2 \text { frontal } \\
\text { tubers }\end{array}$ & $4 \mathrm{y}$ & 0 & - \\
\hline
\end{tabular}

IS=Infantile spasms; PS=partial seizures; SEGA=subependymal giant cell astrocytoma

Table 2 Patients who did not develop subependymal giant cell astrocytomas

\begin{tabular}{|c|c|c|c|c|c|c|c|c|c|}
\hline \multirow[b]{2}{*}{ Patients } & \multirow{2}{*}{$\begin{array}{l}\text { Number of SEN near } \\
\text { foramen of Monro }\end{array}$} & \multicolumn{2}{|l|}{ Diameter } & \multicolumn{3}{|c|}{ Calcification of SEN } & \multirow{2}{*}{$\begin{array}{l}\text { Gadolinium } \\
\text { enhancement }\end{array}$} & \multirow{2}{*}{$\begin{array}{l}\text { Volume } \\
\text { increase }\end{array}$} & \multirow{2}{*}{$\begin{array}{l}\text { Follow up } \\
\text { (y) }\end{array}$} \\
\hline & & $<5 \mathrm{~mm}$ & $>5 \mathrm{~mm}$ & Tot & Part & None & & & \\
\hline 1 & 2 & + & & & & & - & - & 3 \\
\hline 2 & 1 & + & & + & & & - & - & 7 \\
\hline 3 & 3 & + & & + & & & - & - & 18 \\
\hline 4 & 2 & + & & + & & & - & - & 8 \\
\hline 5 & 2 & + & & + & & & - & - & 3 \\
\hline 6 & 1 & & + & + & & & - & - & 3.6 \\
\hline 7 & 1 & + & & + & & & - & - & 4 \\
\hline 8 & 1 & & + & & + & & + & - & 4.8 \\
\hline 9 & 1 & & + & + & & & - & - & 6 \\
\hline 10 & 2 & + & & & & + & + & - & 4.8 \\
\hline 11 & 1 & + & & & & + & Not done & - & 3.7 \\
\hline $12^{\star}$ & 1 & + & & + & & & Not done & - & 8 \\
\hline 13 & 1 & + & & + & & & Not done & - & 4 \\
\hline 14 & 1 & + & & + & & & - & - & 4 \\
\hline $15^{\star}$ & 2 & + & & + & & & - & - & 3 \\
\hline $16^{\star}$ & 1 & & + & + & & & - & - & 6 \\
\hline
\end{tabular}

* These patients did not present nodules on first imaging.

$\mathrm{SEN}=$ subependymal nodule; calcification of SEN : tot=total, part=partial, none $=$ no calcification .

subependymal nodules and eight with subependymal giant cell astrocytomas .

\section{METHODS}

For these 24 patients, we retrospectively reviewed the serial brain examinations, CT and MRI, in a double blind study. We separated this population into two groups:

group 1 comprised 16 patients who presented subependymal nodules near the fo-
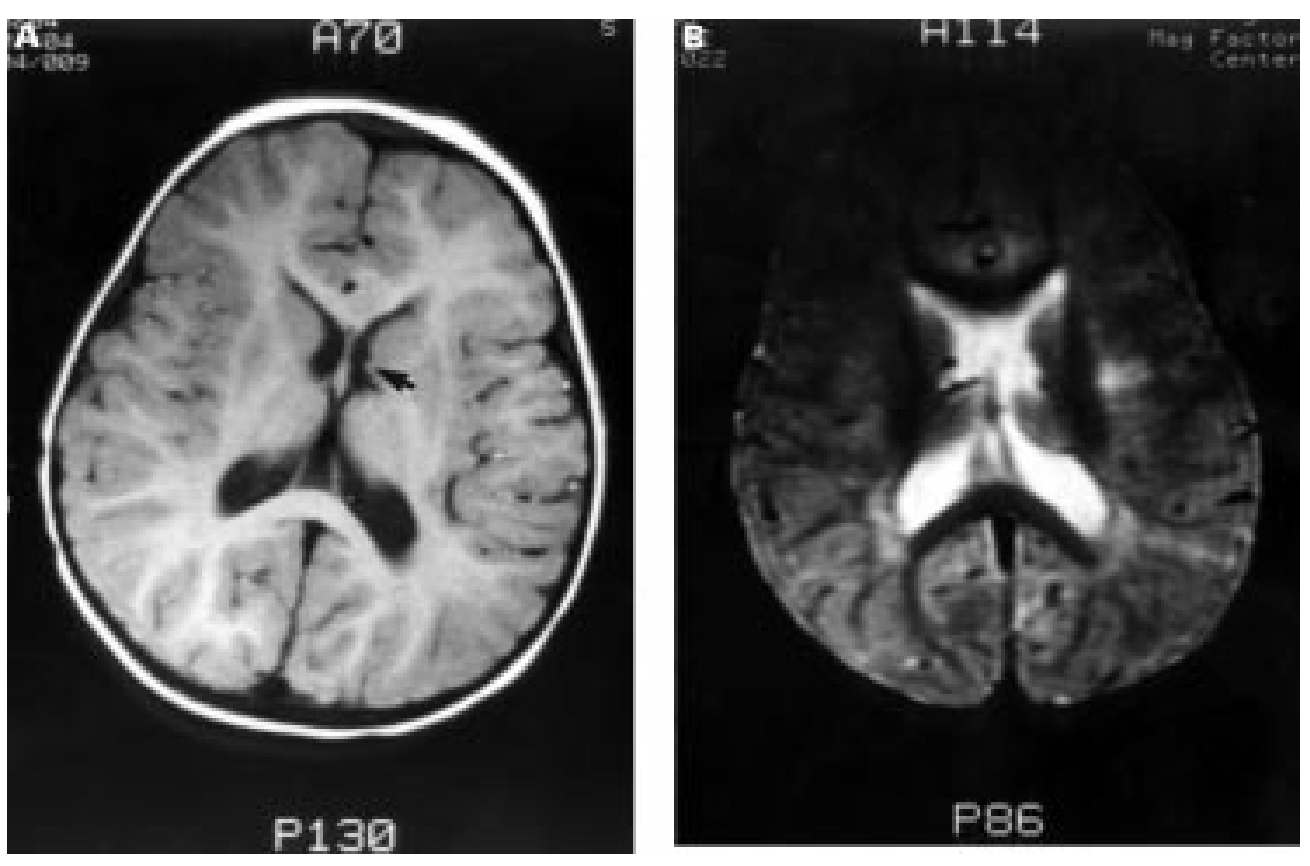

Figure 1 MRI at 1.5 years in patient 4. There was a subependymal nodule in the left foramen of Monro, not calcified, which made the ventricular border irregular (see arrows) in $T 1(A)$ and $T 2(B)$ weighted images .

ramen of Monro but did not develop subependymal giant cell astrocytomas; group 2 comprised eight patients who presented subependymal nodules near the foramen of Monro and developed subependymal giant cell astrocytomas during follow up.

The following definitions were given to the radiologically disclosed lesions: (1) we considered as a subependymal nodule any nonobstructive nodular lesion measuring $<10 \mathrm{~mm}$ 


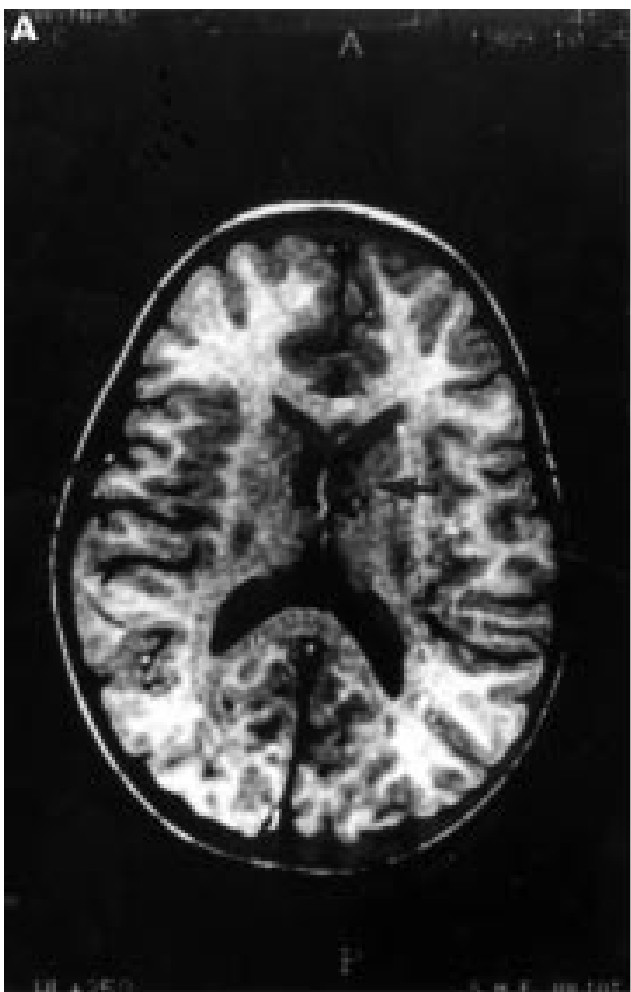

Figure 2 MRI at 4 years in the same patient as in fig $1 ; T$ but still measured $<10 \mathrm{~mm}$ in diameter. It was not calcified.

in diameter; (2) any mass measuring $>10 \mathrm{~mm}$ in diameter with growth more than $5 \mathrm{~mm}$ demonstrated on serial radiological investigations was viewed as subependymal giant cell astrocytomas.

For each CT and MRI, we reviewed the radiological characteristics of subependymal nodules and subependymal giant cell astrocy-

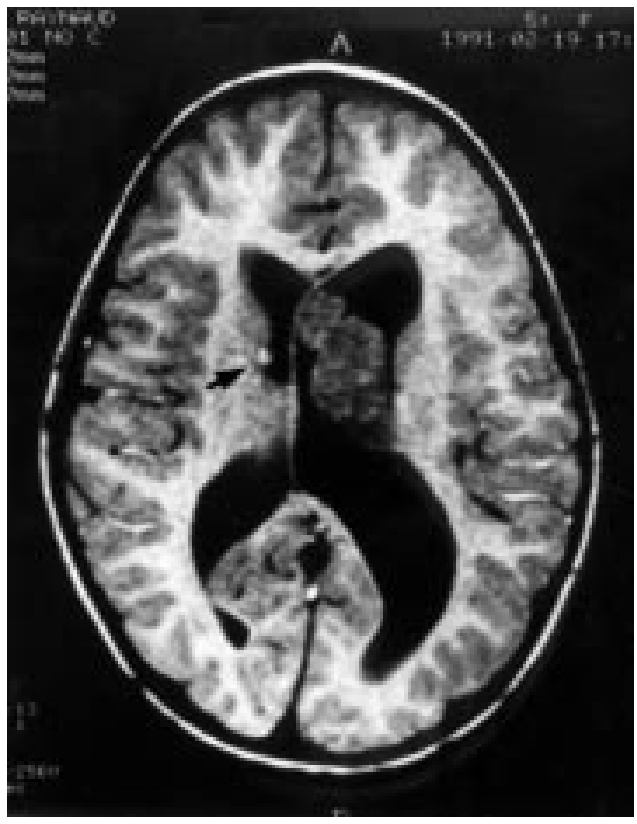

Figure 3 MRI at 6 years in the same patient as in figs 1 and 2; T1 weighted image. The nodule was still growing resulting in a tumour with hydrocephaly and enlargement of the left ventricle. This tumour was clinically asymptomatic, but a surgical exeresis was performed a few months later. Notice that a small nodule is appearing in the other side (arrow).

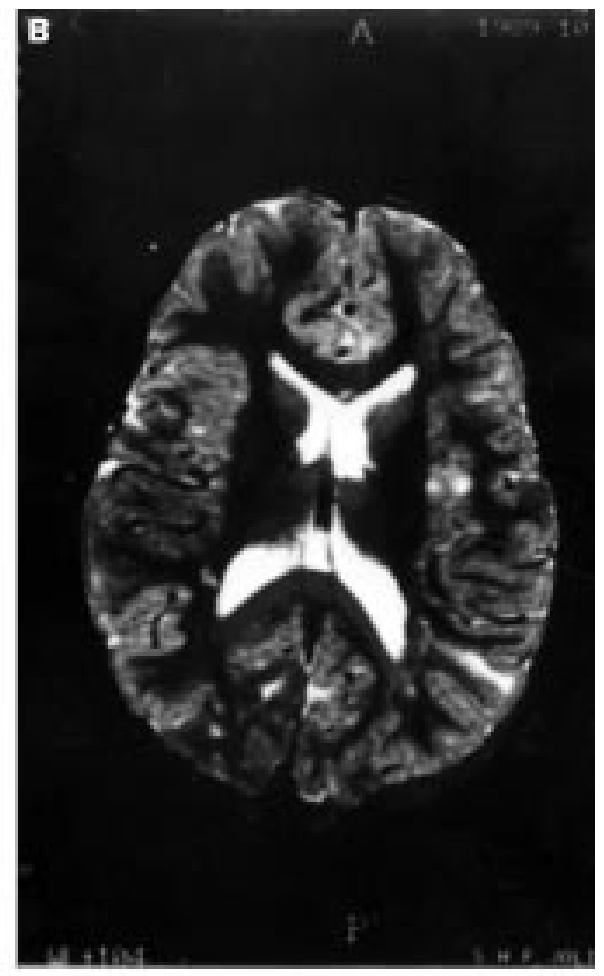

(A) and T2 (B)weighted images. The nodule was growing,

tomas: their numbers and diameters, whether they were calcified (on CT) or enhanced after gadolinium injection (on MRI), and their growth from the previous investigation. We also studied the clinical characteristics of the patients, including those related to the tumour.

Because CT has not been performed in all patients and has been repeated in only a few patients, final radiological characteristics were described on MRI. Sequences and techniques retrospectively analysed in all patients included gradient echo $\mathrm{T} 1$ for axial slices and spin echo T2 for coronal and sometimes axial slices. Size of the mass was retrospectively manually measured in two orthogonal planes and converted to $\mathrm{mm}$ using a scale. The highest value was retained as the "diameter" of the mass.

\section{Results}

In both groups combined, 20 out of the 24 children presented with subependymal nodules at the first cerebral imaging. The four patients without any detectable nodules had had CT as first investigation, before the age of 1 year (table 1). In three of them, MRI was performed before 18 months of age and did not show any nodule.

GROUP 1

In the 16 patients who did not develop subependymal giant cell astrocytomas, the subependymal nodules exhibited special characteristics (table 2). The nodules located near the foramen of Monro were single in 10 patients and multiple in the other six. They were $<5 \mathrm{~mm}$ in 12 . They were completely calcified in 13 patients, all of them measuring $>5$ 


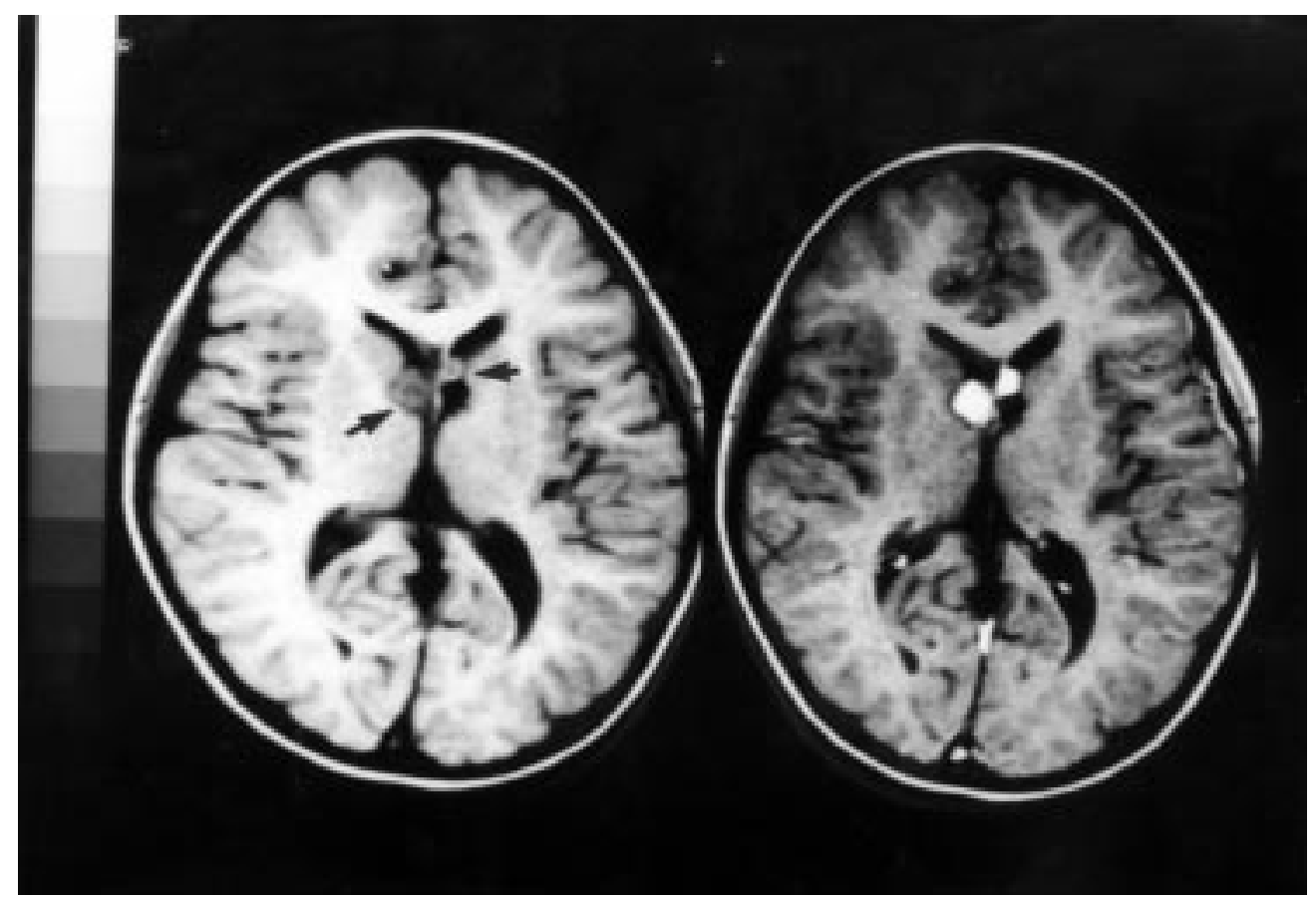

Figure 4 MRI at 7 years in the same patient as in figs 1, 2, and 3; T1 weighted image, without (left) and with (right) gadolinium. The right nodule was growing (arrow) and was enhanced by the contrast. A small part of the operated tumour is remaining at the left side, also enhanced by the contrast.

mm. Gadolinium injection was performed in 13 patients and produced enhancement in only two .

There were no familial antecedents of tuberous sclerosis in this group. Ten patients had had infantile spasms and six partial epilepsy. Follow up ranged from 3 to 18 years (mean 6 years). At the last visit, seven patients were seizure free with antiepileptic drugs but for the four others, epilepsy was only partially controlled. Four children had psychomotor delay although they were seizure free.

GROUP 2

Of the eight patients (five girls, three boys) who developed subependymal giant cell astrocytomas, three were familial. Six had had infantile spasms and two had partial epilepsy. All the patients but one (4) had evidence of subependymal nodules on the first radiological investigation. Patient 4 was the youngest and his first MRI was performed at 2 months of age. The tumours were then first noticed between 1 and 9 years of age (mean 4 years).
Five patients developed intracranial hypertension and were therefore operated on in an emergency setting. Two others were operated on because of evidence of tumour growth on serial radiological examination with signs of obstruction of the ventricular system but in a non-acute situation. The remaining patient has not been operated on yet because the ventricular dilatation remains stable despite the tumour growth. No changes in seizure frequency could be directly correlated with tumour development. All tumours removed underwent neuropathological examination and disclosed typical aspects of subependymal giant cell astrocytomas.

For the seven patients in whom subependymal nodules were detectable on the first imaging, tumours developed at the same place as the nodules (figs 1-4). Subependymal nodules preceding the tumour exhibited common characteristics (table 3 ). They measured $>5 \mathrm{~mm}$ in diameter on first radiological examination except for those in one patient. They were only partially or not at all calcified. This was signifi-

Table 3 Patients who developed subependymal giant cell astrocytoma

\begin{tabular}{|c|c|c|c|c|c|c|c|c|c|c|c|}
\hline Patients & $\begin{array}{l}\text { Age at first } \\
\text { seizure }\end{array}$ & $\begin{array}{l}\text { Seizure } \\
\text { types }\end{array}$ & $\begin{array}{l}\text { Age at first } \\
C T \text { or } M R I\end{array}$ & $\begin{array}{l}\text { SEN } \\
\text { detected } \\
\text { at first } \\
\text { imaging }\end{array}$ & $\begin{array}{l}\text { Number of } \\
\text { SEN near } \\
\text { Monro } \\
\text { foramina }\end{array}$ & $\begin{array}{l}\text { Diameter } \\
>5 \mathrm{~mm}\end{array}$ & $\begin{array}{l}\text { Calcification } \\
\text { of SEN }\end{array}$ & $\begin{array}{l}\text { Gadolinium } \\
\text { enhancement }\end{array}$ & $\begin{array}{l}\text { Volume increase (age at } \\
\text { tumour growth in y) }\end{array}$ & $\begin{array}{l}\text { Ventricular } \\
\text { enlargement }\end{array}$ & Surgery \\
\hline $1^{\star}$ & 3 months & IS & $7 \mathrm{y}$ & + & 1 & + & Part & + & $+($ between $7 \mathrm{y}$ and $9 \mathrm{y}$ ) & - & + \\
\hline 2 & 3 months & IS & $3 y$ & + & 2 & + & Part & - & $+($ at $6 y)$ & $+(\mathrm{ICH})$ & + \\
\hline $3 \ddagger$ & 1 month & IS & $1 \mathrm{y}$ & + & 2 & + & Part & + & + (between $1 \mathrm{y}$ and $3 \mathrm{y})$ & + & + \\
\hline $4 \dagger$ & 1 month & PS & 2 months & - & 1 & + & Part & $+($ at $7 \mathrm{y})$ & + (between $1.5 \mathrm{y}$ and $6 \mathrm{y})$ & + & + \\
\hline $5 \ddagger$ & 8 months & IS & $1 \mathrm{y}$ & + & 1 & + & Part & + & + (between $1 \mathrm{y}$ and $3 \mathrm{y}$ ) & + & + \\
\hline $6 \ddagger$ & 1 month & PS & 8 months & + & 2 & + & Part & + & $+($ between $2 \mathrm{y}$ and $5 \mathrm{y})$ & + & + \\
\hline 7 & 4 months & IS & $1 \mathrm{y}$ & + & 1 & + & Part & - & + (between $6 \mathrm{y}$ and $9 \mathrm{y}$ ) & - & + \\
\hline 8 & 10 months & IS & $3 y$ & + & 1 & + & Part & Not done & $+($ between $3 y$ and $9 y)$ & - & - \\
\hline
\end{tabular}

${ }^{\star}$ The patient died 24 hours after surgery (convulsive status).

† The first CT was performed in 1979 (the patient was referred to SVP 8 years later for intractable epilepsy).

$\ddagger$ These patients have familial tuberous sclerosis.

IS=infantile spasms; $\mathrm{SEN}=$ subependymal nodule; part=partial; $\mathrm{ICH}=$ intracranial hypertension 
cantly different from the group who did not develop tumour ( $p<0.001, \chi^{2}$ test). Enhancement was obtained in five out of the seven patients who underwent gadolinium administration compared with only two out of 13 patients who did not develop tumour $(\mathrm{p}<0.05$, $\chi^{2}$ test).

\section{Discussion}

The present study shows an incidence of $13 \%$ of subependymal giant cell astrocytomas in a paediatric population of tuberous sclerosis. Nodules located near the foramen of Monro, not calcified and enhanced after gadolinium, have a higher probability of evolving into a tumour, particularly in familial cases of tuberous sclerosis. These radiological risk factors can be detected on MRI as early as the age of 1 year. From these data, a regular imaging follow up can be advised for patients with tuberous sclerosis at risk of developing a tumour, to manage its resection in a non-acute situation before the tumour becomes obstructive.

Many recent studies based on clinical and radiological criteria point to a total population prevalence of tuberous sclerosis of between $1 / 10000$ and $1 / 30000 .{ }^{27}$ More than $90 \%$ of the patients have subependymal nodules but $2 \%$ to $14 \%$ of them will develop brain tumours. ${ }^{1781928-30}$ Growth of the tumour is usually reported in adults; in the Mayo Clinic series comprising 355 patients with tuberous sclerosis, $10 \%$ of patients developed subependymal giant cell astrocytomas. ${ }^{24}$ In the present series, the first one dedicated to paediatric patients, we found that $40 \%$ have masses adjacent to the foramen of Monro and that tumour growth can also occur before the age of 10 years, with an incidence similar to that of adults $(13 \%)$. However, these rates are not epidemiologically relevant as our series was limited to a single centre and did not include non-epileptic patients with tuberous sclerosis.

All the tumours adequately identified by histological criteria were subependymal giant cell astrocytomas, in adults as well as in the present paediatric series. Although they are benign in nature and grow slowly, they represent the major cause of death in patients with tuberous sclerosis. $^{7-1027}$ Tumours resulted in death in $50 \%$ of the patients after the age of 10 years in the Mayo Clinic series. ${ }^{78}$ Death occurs because of increased intracranial pressure after misdiagnosed tumour growth, or less commonly after intratumorous haemorrhage. ${ }^{23}$ In the present paediatric series, most patients with brain tumour presented with symptoms of raised intracranial pressure due to obstructive hydrocephalus, and this is consistent with previous reports of patients with subependymal giant cell astrocytomas. Two children were operated on in a non-acute situation because of serial growth disclosed by MRI and growing hydrocephalus. Such a procedure might decrease mortality and morbidity that may be associated with an emergency operation. ${ }^{20-22}$ Using new neurosurgical techniques such as microsurgery or endoscopy, it will be possible in the near future to routinely excise a growing mass, before hydrocephalus appears. ${ }^{31}$
It is important, therefore, to identify risk factors for developing a growing tumour when following up patients with tuberous sclerosis. Clinical features do not seem to be accurate before the occurrence of intracranial hypertension. Although some reports describe subependymal giant cell astrocytomas presenting only with worsening of seizures, ${ }^{17}$ no modification of seizure frequency was noticed in our series. How seizures would relate to the presence of subependymal giant cell astrocytomas is not clear; tubers can act as seizure foci, ${ }^{32}$ but subependymal giant cell astrocytomas themselves are unlikely to provoke seizures, although hydrocephalus may exacerbate a preexisting seizure disorder.

Sequential radioimaging follow up shows that subependymal giant cell astrocytomas correspond to growing subependymal nodules. In the single case without preexisting subependymal nodules, a nodule could have been missed because CT was performed before the age of 1 year and MRI was performed on a first generation instrument. The continuum from subependymal nodules to subependymal giant cell astrocytomas has already been strongly suggested on serial MRIs and neuropathology as the histopathological features of the two entities are identical. ${ }^{9}{ }^{26}$ Moreover, some subependymal nodules do have growing potential as they may be absent on the first imaging, even when performed after 1 year of age, and appear later. subependymal nodules and subependymal giant cell astrocytomas could therefore be considered as a continuum. However, subependymal giant cell astrocytomas involve a minority of patients with tuberous sclerosis whereas subependymal nodules are almost constant features. The subependymal nodules that will turn into tumour seems to have distinct characteristics that could be identified as risk factors: (1) diameter above $5 \mathrm{~mm}$, (2) uncomplete calcification, (3) enhancement after gadolinium administration. These characteristics can be identified as early as 1 year of age. Sequential cerebral radioimaging is the only means of disclosing growing tumours but the adequate frequency for follow up investigation has not been established to date in children, given the need for sedation and cost as limiting constraints. The present study shows that nodules with tumorous potentiality could be identified early in life thus helping to define a high risk population. The minimal interval between the time the mass was detected near the foramen of Monro and the time the mass grew significantly, ranged from 1 to 3 years in our series (table 3 ). It seems, therefore, reasonable to repeat MRI every year in "at risk" children in a preliminary prospective way.

Physiopathological mechanisms underlying tumour growth in tuberous sclerosis are unknown but it is striking that, for retinoblastomas, familial patients seem to exhibit a higher risk for tumour development. ${ }^{33}$ Normal antioncogenes may be deleted or inactivated. Loss of heterozygocity has been demonstrated in tuberous sclerosis astrocytomas, as it has in retinoblastomas. ${ }^{34}$ The risk for a second muta- 
tion is indeed particularly higher in patients who have inherited the disorder, and whose cells therefore carry the first mutation. ${ }^{35}$

\section{Conclusion}

We propose the following for children with tuberous sclerosis: MRI with and without gadolinium administration should be performed at the time of diagnosis of tuberous sclerosis and at the age of 2 years. When there are nodules located near the foramen of Monro and if they measure $>5 \mathrm{~mm}$ in diameter, are not or incompletely calcified, and are enhanced by gadolinium, MRI should be repeated every year until the age of 10 years, particularly in patients with a family history of tuberous sclerosis. Re-evaluation of this procedure should be performed periodically in a prospective study to select more appropriately the indications and date for neuroimaging. Further follow up would also determine whether subependymal nodules and subependymal giant astrocytomas can be considered as two distinct lesions with respect of their growth potential.

We are very grateful to Anne Dugardin for her technical assistance.

1 Shepherd CW, Scheithauer B, Gomez MR. Brain tumors in tuberous sclerosis: a clinicopathologic study of the Mayo clinic experience. Mayo Clin Proc 1991;66:378-9.

2 Ahluwalia CK, Chandrasoma PT. Cytomorphology of subependymal giant cell astrocytoma: a case report. Acta Cyto 1993:37:197-200

3 Alman NR, Purser RK, Donovan Post MJ. Tuberous sclerosis: characteristics at $\mathrm{CT}$ and MR imaging. Radiology 1998;167:527-32

4 Bancel B, Belin MF, Meiniel A, et al. Contribution à l'étude de l'histogenèse des gliomes sous-épendymaires de la sclérose tubéreuse de Bourneville. Ann Pathol 1990;10: 109-16.

5 Bender BL, Yunis EJ. Central nervous system pathology of tuberous sclerosis in children. Ultrastruct Pathol 1980;1: 287-99.

6 Iwasaki Y, Yoshikawa H, Sasaki M, et al. Clinical and immunohistochemical studies of subependymal giant cell astro-
cytomas associated with tuberous sclerosis. Brain Dev cytomas associated

7 Shepherd CW, Gomez MR. Mortality in the Mayo clinic tuberous sclerosis complex study. N Y Ann Acad Sc 19; 615:375-7.

8 Shepherd CW, Gomez MR, Lie JT, et al. Causes of death in patients with tuberous sclerosis. Mayo Clin Proc 1991;66 $792-6$.

9 Fujiwara S, Takaki T, Hikita T, et al. Subependymal giant-cell astrocytoma associated with tuberous sclerosis: do subependymal nodules grow ? Child's Nerv Syst 1989;5: 43-4.

10 Webb DW, Fryer AE, Osborne JP. Morbidity associated with tuberous sclerosis: a population study. Dev Med Child Neurol 1996;38:146-55.
11 Prahlow JA, Teot LA, Lantz PE, et al. Sudden death in epilepsy due to an isolated subependymal giant cell astrocyoma of the septum pellucidum. Am f Forensic Med Pathol 1995;16:30-7.

12 Nagib MG, Haines SJ, Erickson DL, et al. Tuberous sclerosis: a review for the neurosurgeon. Neurosurgery 1984;14:96-8.

13 McLaurin RL, Towbin RB. Tuberous sclerosis: diagnostic and surgical considerations. Pediatr Neurosci 1985-86;12: $43-8$.

14 Braffman BH, Bilaniuk LT, Naidich TP, et al. Imaging of tuberous sclerosis: pathogenesis of this phacomatosis, use of guadolinium dimeglumine and literature review. Radiology 1992;183:227-38.

15 Tien RD, Hesselik JR, Duberg A. Rare subependymal giant cell astrocytoma in a neonate with tuberous sclerosis. AfNR Am f Neuroradiol 1990;11:1251-2.

16 Buki A, Horvath Z, Kover F, et al. Occlusive hydrocephalus complicating tuberous sclerosis: report of two cases. Eur $\mathcal{F}$ Neurol 1996;3:255-9.

17 Frerebeau Ph, Benezech J, Segnarbieux F, et al. Intraventricular tumors in tuberous sclerosis. Child's Nerv Syst 1985;1:45-8.

18 Kapp JP, Paulson GW, Odom GL. Brain tumors with tuberous sclerosis. F Neurosurg 1967;26:191-202.

19 Kingsley DPE, Kendall BE, Fitz CR. Tuberous sclerosis: a clinicoradiological evaluation of 110 cases with particular reference to atypical presentation. Neuroradiology $1986 ; 28$ : $38-46$.

20 Morimoto K, Mogami H. Sequential CT study of subependymal giant cell astrocytoma associated with subependymal giant cell astrocytoma asso

21 Sinson G, Sutton LN, Yachnis AT, et al. Subependymal giant cell astrocytomas in children. Pediatr Neurosurg 1994; 20:133-9.

22 Tsuchida T, Kamata K, Kawamata M. Brain tumors in tuberous sclerosis: report of four cases. Childs Brain 1981; 8:271-83.

23 Waga S, Yamamoto Y, Kojima T, et al. Massive hemorrhage in tumor of tuberous sclerosis. Surg Neurol 1977;8:99-101.

24 Maki Y, Enomoto T, Maruyama H, et al. Computed tomography in tuberous sclerosis. Brain Dev 1979;1:38-48.

25 Terwey B, Doose H. Tuberous sclerosis: magnetic imaging of the brain. Neuropaediatrie1987;18:67-9.

26 Roach ES, Williams DP, Laster DW. Magnetic resonance in tuberous sclerosis. Arch Neurol 1987;44:301-3.

27 Gomez MR. The phakomatoses. In: Gomez MR, ed. Tuberous sclerosis. New York: Raven Press, 1998, 16-20.

28 Shepherd CW, Scheithauer BW, Gomez MR, et al. Subependymal giant cell astrocytoma: a clinical, pathologi$\mathrm{cal}$, and flow cytometric study. Neurosurgery 1991;28:8648.

29 Taptas JN, Kordiolis N, Charalambopoulos F. Formes tumorales de la sclérose tubéreuse de Bourneville: l'importance de l'hydrocéphalie dans la symptomatologie et le traitement. Neurochirurgie 1978;24:113-16.

30 Boesel CP, Paulson GW, Kosnik EJ. Brain hamartomas and tumors associated with tuberous sclerosis. Neurosurgery 1979;4:410-7.

31 Kelly PJ. Stereotactic craniotomy. Neurosurg Clin N Am $1990 ; 1: 781-99$.

32 Cusmai R, Chiron C, Curatolo P, et al. A topographic comparative study on MRI an EEG in 34 children with tuberous sclerosis. Epilepsia 1990;31:747-55.

33 Onadim Z, Hogg A, Cowell JK. Mechanisms of oncogenesis in patients with familial retinoblastoma. Br f Cancer 1993; 68:958-64.

34 Kato MV, Shimizu T, Ishizaki K, et al. Loss of heterozygosity on chromosome 17 and mutation of the p53 gene in retinoblastoma. Cancer Lett 1996;106:75-82.

35 CRC Human Cancer Genetics Research Group. The role of gene mutaions in the genesis of familial cancers. FASEB 7 1993;7:910-19. 